\title{
PERUNUTAN ALIRAN SUNGAI BAWAH TANAH DALAM RANGKA PENGEMBANGAN SUMBER DAYA AIR DAERAH KARST
}

\section{TRACKING THE UNDERGROUND RIVER IN THE DEVELOPMENT OF WATER RESOURCES IN THE KARST AREAS}

\author{
Heni Rengganis ${ }^{1)}$, Wawan Herawan ${ }^{2)}$, Wulan Seizarwati ${ }^{3)}$ \\ 1,2,3)Pusat Penelitian dan Pengembangan Sumber Daya Air \\ Jl. Ir. H. Juanda 193, Bandung, Jawa Barat, Indonesia. \\ E-mail : henirengganis@yahoo.com
}

Diterima: 16 Desember 2015; Direvisi: Januari 2016; Disetujui: 14 maret 2016

\begin{abstract}
ABSTRAK
Tracer technique dikenal secara luas sebagai salah satu metode yang digunakan untuk mencari hubungan antar goa atau sistem sungai bawah tanah di daerah karst. Di daerah karst Blitar Selatan telah teridentifikasi sejumlah sumber air berupa mata air, sungai bawah tanah, dan beberapa aliran sungai yang keluar menuju ke laut Selatan. Perunutan aliran sungai bawah tanah menggunakan tracer technique telah dilaksanakan dengan tujuan untuk mendapatkan data dan informasi sistem aliran di sekitar Goa Umbul Tuk, sehingga sumber air ini selanjutnya dapat dikembangkan pemanfaatannya sebagai nilai tambah penyediaan air baku di Kabupaten Blitar. Pengujian dilaksanakan dengan menggunakan bahan perunut buatan berupa garam NaCl dan pengukuran dilakukan dengan menggunakan alat ukur daya hantar listrik (EC meter). Hasil pengukuran menunjukkan adanya alur sungai bawah tanah yang menghubungkan antara Goa Rowo dengan Goa Umbul Tuk, dengan debit aliran terusan dari Umbul Tuk menuju Laut Selatan sebesar $360 \mathrm{l} / \mathrm{s}$ (Maret 2012), yang sangat berpotensi untuk dimanfaatkan. Pemanfaatan aliran ini, selain untuk kebutuhan penduduk sekitar, berpotensi juga untuk pemenuhan kebutuhan pariwisata baru di pantai Pangi Laut Selatan, yang mana pada saat ini masih belum dikembangkan.
\end{abstract}

Kata kunci: Sumber air, karst, perunut, goa, sungai bawah tanah

\section{ABSTRACT}

Tracer technique is widely known as one of the methods used to find the relationship between the cave or underground river system in karst areas of South Blitar. In karst area of south blitar karst areas a number of water sources such as springs, underground river, and some streams out into the South Sea trace connections among tracing the flow of underground river using tracer technique has been implemented with the aim to obtain data and information on flow systems around Umbul Tuk caves, so that water resources can be further developed as a value-added utilization of raw water supply in Blitar. Testing was conducted using artificial tracer material in the form of common salt $\mathrm{NaCl}$ and measurements were performed using a measuring instrument electrical conductivity (EC). The measurement results indicate the existence of an underground river channel that connects Rowo with Umbul Tuk, with a flow rate of Umbul Tuk canal towards the South Sea of $360 \mathrm{l} / \mathrm{s}$ (March 2012), which has the potential to be exploited. Utilization of this flow, in addition to the needs of local people, and potentially also for fulfilling the needs of the new tourism in Pangi coast of the South Sea, which at present is still not developed.

Keyword: Water resources, karst, tracer, caves, underground river

\section{PENDAHULUAN}

Kekurangan air untuk pemenuhan berbagai kebutuhan dapat mengakibatkan suatu daerah tidak dapat berkembang dengan baik. Oleh karena itu, ketersediaan air baku menjadi sangat penting, tidak hanya untuk meningkatkan kesejahteraan masyarakat, namun juga diperlukan untuk pengembangan wilayah. Perkembangan wilayah di daerah Jawa Timur bagian selatan khususnya di daerah karst pada umumnya jauh tertinggal dibanding Pulau Jawa bagian utara atau daerah lainnya. Keadaan wilayah dengan karakteristik daerah yang ditutupi dengan morfologi karst, menyebabkan sulitnya mendapatkan air baku untuk mencukupi berbagai kebutuhan. Karakteristik daerah karst yang unik dan khas diperlukan pengelolaan khusus, terutama yang 
berkaitan dengan penyediaan dan pemanfaatan sumber-sumber air yang ada.

Karst adalah bentang alam di permukaan dan perut bumi, yang secara khas berkembang pada batu gamping dan dolomit sebagai akibat proses pelarutan dan peresapan air. Di Indonesia, potensi karst terdapat di pulau-pulau seperti Sumatera, Jawa, Kalimantan, Bali, Lombok, NTB, Timor, Sulawesi, Maluku, dan Papua. Di Pulau Jawa, sebaran kawasan karst terdapat di Rembang, Bojonegoro, Pangandaran, Tulungagung, Blitar, Surabaya, Kangean, Balekambang, Bawean, Mojokerto, Pacitan, Wonogiri, Wonosari, Purwokerto, Tegal, Cianjur, Bogor, Salatiga, Surakarta, Besuki, Tuban, Sumenep, Pamekasan, Banyuwangi, Ponorogo, Jember, Yogyakarta, Subang, Bandung, dan Karawang. (Puslitbang Sumber Daya Air, 2012).

Pada saat ini informasi potensi sumber daya air di wilayah karst khususnya di Blitar Selatan sangat terbatas, oleh karena itu salah satu upaya dalam rangka mengembangkan sumber daya air pada daerah ini, perlu diketahuinya informasi mengenai potensi sumber air. Ketersediaan data dan informasi sangat menentukan dalam rencana pemanfaatan air selanjutnya.

Sumber-sumber air yang terdeteksi di kawasan Karst Blitar Selatan berupa sungai permukaan, sungai bawah tanah, mata air, sumur dan telaga. Lebih dari 20 (dua puluh) buah mata air telah teridentifikasi dengan besaran debit terukur bervariasi dari 1 l/s sampai dengan 60 l/s dan telah dimanfaatkan oleh penduduk untuk kebutuhan sehari-hari. Beberapa aliran sungai bawah tanah teridentifikasi, diantaranya aliran di mulut Goa Rowo, Goa Umbul Tuk dan aliran sungai dari Umbul Gedhang yang berpotensi untuk dimanfaatkan dan dikembangkan. Pada saat ini, sumber air tersebut belum dimanfaatkan secara optimal, karena sisa aliran masih terbuang percuma menuju laut Selatan, (Puslitbang Sumber Daya Air, 2012).

Sumber-sumber air yang ada di kawasan Karst Blitar Selatan, pada saat ini masih belum bisa dimanfaatkan semuanya, terkendala dengan kondisi geomorfologi yang sulit dijangkau, sehingga perlu pengaturan dengan melibatkan pemerintah dan masyarakat sekitar lokasi sumber air tersebut. Berbagai teknik pemanfaatan dan pengambilan air telah dilakukan oleh masyarakat setempat, diantaranya dengan cara memompa dari sumber air yang ada dibawah secara estafet menggunakan lebih dari satu pompa sejauh \pm 1 $\mathrm{km}$ menuju area pemukiman penduduk yang berada diatas. Teknik pengambilan ini masyarakat terkendala dengan biaya energi yang harus dikeluarkan menjadi lebih mahal. Teknik pemanfaatan sumber air lainnya yang telah dilakukan oleh penduduk sekitar adalah melakukan kegiatan di lokasi sumber air tersebut. Hal ini sangat berbahaya apabila dilakukan menerus, yaitu lingkungan sumber air tersebut menjadi tercemar dan mempengaruhi air di bagian hilir aliran yang sampai saat ini masih dimanfaatkan.

Tracer Technique dikenal secara luas sebagai salah satu metode yang dapat digunakan untuk mencari hubungan antar goa atau sistem sungai bawah tanah di akuifer karst. Kegiatan serupa untuk mengungkap hubungan aliran antara Goa Rowo dan Goa Umbul Tuk tersebut pernah dilakukan dengan pemetaan alur sungai bawah tanah. Metode yang digunakan dengan pengukuran geolistrik tomografi, dimulai dari bagian hulu Goa Rowo keluar di bagian hilirnya Goa Umbul Tuk sepanjang $\pm 1300 \mathrm{~m}$ (Aditya.Y. , A.S. Soewaeli. , 2014)

Secara sederhana tracer technique adalah memasukkan atau menuang sesuatu bahan perunut pada aliran air atau sungai yang akan masuk ke goa, kemudian menjemput pada suatu lokasi yang diperkirakan mempunyai hubungan dengan titik awal lokasi memasukkan bahan perunut tadi. Apabila bahan perunut terdeteksi secara fisik ataupun dengan alat pengukur yang lain maka dapat dipastikan bahwa terdapat hubungan antara titik awal dengan titik kedua tempat kita mencegat bahan perunut tersebut.

Pada penelitian ini dirancang untuk menjawab pertanyaan utama dalam rangka pemanfaatan sungai bawah tanah, yaitu kemana air dari suatu goa mengalir atau dari mana asalnya dan berapa lama waktu yang dibutuhkan untuk mencapai keluaran tertentu? Dengan diketahuinya pola keterhubungan antara sistem sungai bawah tanah akan dapat memperkirakan jumlah air yang dapat dimanfaatkan secara berkelanjutan. Informasi hasil yang dicapai dalam penelitian ini diharapkan menjadi masukan dalam perencanaan pengembangan sumber daya air karst di wilayah tersebut sekaligus pengembangan wilayah di sekitarnya.

Tulisan ini menyajikan hasil kegiatan perunutan aliran sungai bawah tanah dengan menggunakan tracer technique yang akan mengungkap hubungan sistem aliran air tanah Goa Rowo dan Goa Umbul Tuk. Selanjutnya diketahui pula sistim aliran terusan dari Umbul Tuk yang menuju laut Selatan, sehingga aliran sumber air ini dapat dikembangkan dan berpotensi untuk dimanfaatkan selanjutnya. 


\section{Lokasi Pengujian}

Goa Rowo berada di Dusun Kalimeneng, Desa Sidomulyo, Kecamatan Bakung, Kabupaten Blitar yang diperkirakan merupakan masukan dari aliran sungai bawah tanah dan keluar melalui goa Umbul Tuk (Gambar1). Goa Umbul Tuk merupakan goa alam yang diperkirakan merupakan aliran keluaran dari Goa Rowo, didalamnya penuh dengan stalagmit dan stalaktit, terletak di Desa Tumpak Kepuh, Kecamatan Bakung, arah selatan Kota Blitar dengan jarak sekitar $40 \mathrm{~km}$.

Panjang goa ini sekitar 1300 meter sedang luas dan tingginya sekitar 3 meter. Berdasarkan informasi dari Dinas Parawisata Goa Umbul Tuk merupakan satu-satunya goa di Blitar yang menyajikan keunikan stalagmitnya. (Haryono, 2014)

\section{KAJIAN PUSTAKA}

\section{Uji Perunut}

Uji perunut digunakan dalam penyelidikan air tanah terutama pada penentuan arah aliran air tanah, waktu tinggal air, pengukuran karakteristik akuifer, pemetaan dan karakteristik aliran di daerah karst. Uji perunut sering dilakukan pada akuifer karst, yaitu untuk menunjukkan hubungan aliran yang satu ke yang lainnya dan mengetahui jaraknya. Dalam akuifer antar butir, uji perunut jarang digunakan karena kecepatan air tanah lebih lambat. Agar uji ini bermanfaat dan berhasil, digunakan bahan perunut yang tidak beracun dan mudah diukur pada aliran air yang sangat encer. (Hiscock K, 2005).

Pilihan jenis perunut tergantung pada kesesuaian dalam hal pendeteksian, toksisitas, biaya relatif murah dan kemudahan penggunaan. Metode uji perunut ditentukan oleh sifat hidrogeologi yang akan diukur. Berbagai metode uji perunut bisa digunakan tergantung tujuan yang akan diperoleh dan diharapkan. Sebagai contoh dalam menentukan jalur suatu aliran pada 2 (dua) titik atau lebih serta menentukan arah alirannya saja dapat dilakukan dengan beberapa metode uji perunut, seperti ditampilkan pada Tabel 1.

\section{Zat Perunut}

Zat Perunut dalam hidrogeologi adalah bahan atau energi yang dibawa oleh air yang akan memberikan informasi mengenai arah dan kecepatan air serta kontaminan potensial yang terbawa oleh air (Davis, et.al, 1985). Perunut berupa zat alami (natural tracer) atau buatan (artificial tracer) yang dapat terdeteksi meskipun dalam jumlah yang sangat sedikit (Uhlenbrook, 2010).

Perunut buatan diantaranya garam, zat warna fluorescence, koloid dan partikel melayang seperti spora, virus, dan bakteri. Perunut alami diantaranya isotop stabil (deuterium, oksigen-18) isotop radioaktif (tritium), perunut hidrokimia, dan perunut pencemar. Perunut alami memiliki keterbatasan diantaranya membutuhkan skala yang luas jika dibandingkan dengan perunut buatan, variabilitas spasial-temporal inputnya sulit untuk diamati, dan membutuhkan biaya yang cukup besar. Perunut buatan membutuhkan waktu, lokasi, dan situasi hidrologis yang spesifik, serta memiliki keterbatasan spasial dan temporal. Zat perunut buatan dapat dikelompokkan menjadi zat yang reaktif dan tidak reaktif atau dapat juga dibagi menjadi zat terlarut dan partikel. Tabel 2 menyajikan jenis-jenis zat perunut yang dapat digunakan dalam penyelidikan air tanah. Zat warna fluorescent adalah senyawa organik sintetik yang dapat menyerap cahaya dengan panjang gelombang spesifik dan memancarkan cahaya fluorescent pada panjang gelombang yang lebih panjang.

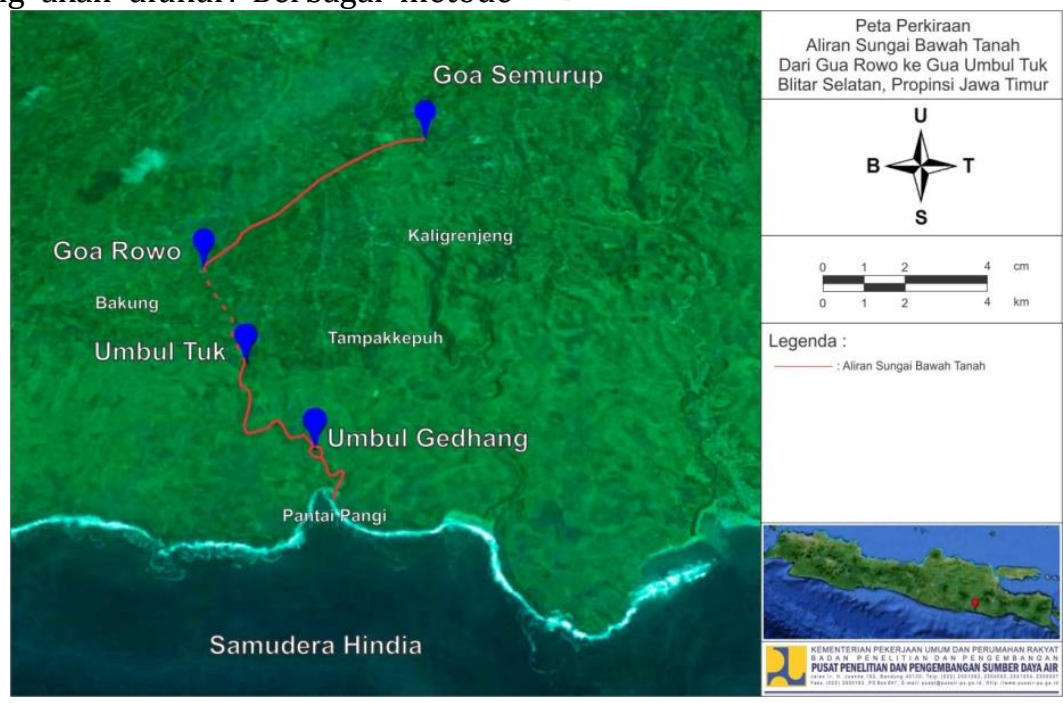

Gambar 1 Lokasi Pengujian 
Beberapa aplikasi, zat warna fluorescent seperti uranine hijau (sodium fluorescent) dipilih untuk perunutan aliran air tanah karena mudah larut, tidak mahal, aman/tidak beracun, dan memiliki batas deteksi yang sangat rendah yaitu $0.005 \mu \mathrm{g} / \mathrm{L}$.

Pengujian dengan teknik perunutan yang lebih spesifik dapat digunakan Litium, Kalium, dan Strontium sebagai zat perunut kation, sedangkan Bromida dan Iodida dapat digunakan sebagai zat perunut anion. Penggunaan 2 (dua) zat tersebut dengan konsentrasi yang sangat tinggi dapat berbahaya bagi biota air. Pemilihan zat perunut bergantung pada analisis dampaknya terhadap lingkungan (Benrens et al, 2001 dalam Goldscheider, et.al, 2007), harga, dan kemampuan mendeteksi. Dalam aliran air tanah di daerah Karst, uranine adalah pilihan pertama.

Zat perunut berupa partikel berguna untuk penyelidikan transport dan atenuasi kontaminan dan mikroba patogen. Garam adalah pilihan yang baik untuk digunakan sebagai bahan perunut jarak pendek dan apabila menggunakan zat warna di area dekat pemukiman sebaiknya harus dihindari. Akan tetapi penggunaan larutan garam sebagai bahan perunut membutuhkan jumlah yang relatif lebih banyak dibandingkan zat warna fluorescent.

Jumlah bahan perunut yang dibutuhkan bergantung pada sifat teknik perunutan dan tipe alirannya. Persamaan yang umum digunakan dan sangat sederhana diusulkan oleh Kass (1998) dalam Goldscheider, et.al, (2007) sebagai berikut.

$$
\mathrm{M}=\mathrm{LkB} \text {.. }
$$

Dimana:

$\mathrm{M}=$ jumlah bahan, misalnya massa $(\mathrm{kg})$ atau jumlah partikel

$\mathrm{L}=\operatorname{jarak}(\mathrm{km})$

$\mathrm{k}=$ koefisien perunut (uranine $=1$, zat warna fluorescent lainnya $=2-15$ garam $=1000-20000$, partikel $=10^{-12}-10^{-13}$ )

$\mathrm{B}=$ faktor kondisi hidrogeologi $(0.1-0.9$ untuk akuifer Karst)

\section{Perunutan menggunakan Larutan Garam $\mathrm{NaCl}$}

Beberapa sifat dari perunut larutan garam diantaranya merupakan senyawa anorganik, dalam fasa padat memiliki titik leleh tinggi, rapuh, dan memiliki kisi yang kuat, di dalam air akan terpisah menjadi anion dan kation (mudah bergerak dan mengandung arus listrik), dapat juga digunakan untuk tracer alami hidrokimia, serta sering digunakan di sungai untuk menentukan kecepatan aliran dan debit (Uhlenbrook, 2010). Beberapa larutan garam yang sering digunakan untuk tracer diantaranya $\mathrm{NaCl}, \mathrm{KCl}$, $\mathrm{LiCl}, \mathrm{HBO}_{2}, \mathrm{NaBr}$, dan $\mathrm{NaI}$.

Tabel 1 Sifat hidrogeologi yang dapat diukur menggunakan uji perunut

\begin{tabular}{|c|c|c|c|}
\hline NO & Uraian & $\begin{array}{c}\text { Metode uji yang } \\
\text { sesuai }\end{array}$ & Metode uji perunut \\
\hline 1 & $\begin{array}{l}\text { Mengukur jalur aliran : } \\
\text { - } 2 \text { titik atau lebih } \\
\text { - arah aliran }\end{array}$ & $\begin{array}{l}3 ; 4 ; 6 \\
3 ; 4\end{array}$ & $\begin{array}{l}\text { 1. Uji Laboratorium } \\
\text { 2. Pelarutan lubang bor } \\
\text { tunggal }\end{array}$ \\
\hline 2 & $\begin{array}{l}\text { Mengukur kecepatan: } \\
\text { - Kecepatan air linear rata } \\
\text { - Debit spesifik / kecepatan darcy } \\
\text { - Kecepatan migrasi kontaminan }\end{array}$ & $\begin{array}{l}3 ; 4 ; 5 ; 6 \\
2 \\
3 ; 4 ; 6\end{array}$ & $\begin{array}{l}\text { 3. Uji gradien alami tanpa } \\
\text { lubang bor } \\
\text { 4. Alami dengan banyak } \\
\text { lubang bor }\end{array}$ \\
\hline 3 & $\begin{array}{l}\text { Mengukur sifat akuifer. } \\
\text { - konduktivitas hidrolik } \\
\text { - porositas efektif } \\
\text { - heterogenitas } \\
\text { - karakterisasi rekahan } \\
\text { - Matrix penyebaran }\end{array}$ & $\begin{array}{l}2 \\
5 \\
4 \\
4 \\
1 ; 6 ; 4\end{array}$ & $\begin{array}{l}\text { 5. Injeksi dan } \\
\text { pemompaan kembali } \\
\text { 6. Uji gradien buatan } \\
\text { banyak lubang bor }\end{array}$ \\
\hline 4 & $\begin{array}{l}\text { Mengukur zat terlarut/sifat kandungan zat } \\
\text { pencemar } \\
\text { - penyebaran } \\
\text { - resapan } \\
\text { - pengenceran }\end{array}$ & $\begin{array}{l}3 ; 4 ; 5 ; 6 \\
1 ; 4 \\
3 ; 4 ; 6\end{array}$ & \\
\hline 5 & Mengkukur resapan/tangkapan air tanah & $3 ; 4$ & \\
\hline 6 & Mengukur umur air tanah & $3 ; 4$ & \\
\hline
\end{tabular}

Sumber: Hiscock K (2005) 
Tabel 2 Zat perunut buatan

\begin{tabular}{|c|c|c|c|c|}
\hline Kelompok & Nama Zat perunut & Batas Deteksi & Masalah Umum & Masalah Khusus \\
\hline \multirow{8}{*}{$\begin{array}{l}\text { Zat warna } \\
\text { fluorescent }\end{array}$} & Uranine* & $10^{-3} \mu \mathrm{g} / \mathrm{L}$ & \multirow{4}{*}{$\begin{array}{l}\text { Sensitif terhadap cahaya dan } \\
\text { oksidan yang kuat }\end{array}$} & - \\
\hline & Eosin* & \multirow{5}{*}{$10^{-2} \mu \mathrm{g} / \mathrm{L}$} & & - \\
\hline & Amidorhodamine G* & & & - \\
\hline & Sulforhodamine B & & & Pencemar \\
\hline & Rhodamine WT & & \multirow{4}{*}{$\begin{array}{l}\text { Gangguan analitik antara zat } \\
\text { warna fluorescent dari sifat } \\
\text { optikal yang sama }\end{array}$} & Genotoksik \\
\hline & Pyranine* & & & Terurai \\
\hline & Naphthionate* & \multirow{2}{*}{$10^{-1} \mu \mathrm{g} / \mathrm{L}$} & & \multirow{2}{*}{$\begin{array}{l}\text { Gangguan analitik } \\
\text { (optikal) dengan DOC }\end{array}$} \\
\hline & Tinopal CBS-X* & & & \\
\hline \multirow{7}{*}{ Garam } & Natrium (Na) & \multirow{7}{*}{$10^{-3}-0.1 \mu \mathrm{g} / \mathrm{L}$} & \multirow{7}{*}{$\begin{array}{l}\text { Serapan kation } \\
\text { (Sr }>\mathrm{K}>\mathrm{Na}>\mathrm{Li}) \\
\text { Berubah - ubah dan } \\
\text { kadangkala secara alamiah } \\
\text { sudah tinggi, khususnya } \mathrm{Na} \\
\text { dan } \mathrm{Cl}\end{array}$} & - \\
\hline & Kalium (K) & & & - \\
\hline & Litium (Li) & & & - \\
\hline & Strontium $(\mathrm{Sr})$ & & & - \\
\hline & Klorida (Cl) & & & - \\
\hline & Bromida (Br) & & & $\begin{array}{l}\text { Dapat membentuk } \\
\text { senyawa berbahaya }\end{array}$ \\
\hline & lodida & & & $\begin{array}{l}\text { Tidak stabil secara } \\
\text { biokimia }\end{array}$ \\
\hline \multirow{3}{*}{ Partikel } & $\begin{array}{l}\text { Fluorescent } \\
\text { microspheres* }\end{array}$ & \multirow{3}{*}{$\begin{array}{l}\text { Deteksi partikel } \\
\text { tunggal }\end{array}$} & \multirow{3}{*}{$\begin{array}{l}\text { Analisis relatif membutuhkan } \\
\text { banyak waktu. } \\
\text { Mudah disaring }\end{array}$} & - \\
\hline & Bakteri & & & \multirow{2}{*}{$\begin{array}{l}\text { Kestabilan terbatas } \\
\text { (inaktivasi) analisis } \\
\text { dalam } 24 \text { jam }\end{array}$} \\
\hline & Bacteriophages & & & \\
\hline
\end{tabular}

Sumber : Goldscheider, et.al, 2008

Kelebihan menggunakan perunut larutan garam diantaranya yaitu analisis mudah dilakukan bahkan cukup dengan mengukur nilai daya hantar listrik (EC), transparan dan tidak terlihat (invisible), tidak berbahaya bagi lingkungan (dalam konsentrasi rendah), dan biaya terjangkau. Meski begitu jenis perunut ini pun memiliki kekurangan diantaranya seringkali dibutuhkan konsentrasi yang tinggi, jumlah yang besar kemungkinan dapat mengubah aliran lokal (densitas), dapat menyebabkan pertukaran ion, dan jika jumlah yang digunakan banyak maka membutuhkan biaya yang juga relatif banyak (Uhlenbrook, 2010).

Sejumlah larutan garam dapat ditumpahkan pada inlet suatu sistem, kemudian diukur perubahan nilai daya hantar listrik (EC) pada outlet atau dengan mengukur parameter kimia lainnya dengan dengan metoda lain (Bruckner, 2012). Metode ini efektif digunakan untuk perunut air tanah, tetapi perlu diketahui bahwa pergerakan air dalam tanah pun bisa saja menambah kadar garam yang terkandung. Oleh karena itu sebelum perunutan dilakukan perlu dipelajari terlebih dahulu litologi batuan setempat. Ketika memutuskan untuk menggunakan larutan garam dalam teknik perunut, maka perlu juga diukur sifat konservatif dari garam yang digunakan karena ion garam yang dimasukkan bisa saja bereaksi dengan air atau sedimen terlarut sehingga tidak dapat pergi meninggalkan sistem. Sebagai contoh, Khlorida merupakan perunut yang berguna karena bersifat inert (tidak mudah bereaksi) dan tidak digunakan oleh biota dalam jumlah yang banyak. Nitrat merupakan zat perunut yang buruk karena kemungkinan dapat diserap oleh biota sebelum meninggalkan sistem.

\section{Pengujian Arah Aliran Sungai Bawah Tanah oleh peneliti lain}

Metoda lain yang dapat digunakan untuk memetakan alur sungai bawah tanah adalah dengan pengukuran geolistrik. Pemetaan alur Goa Rowo-Umbul Tuk pernah dilakukan, dimulai dari bagian hulu (Goa Rowo) dimana air masuk, lalu 
mengikuti jejak sungai bawah tanah tersebut yang diperkirakan mengalir ke arah tenggara hingga keluar di bagian hilirnya (Goa Umbul Tuk) yang selanjutnya mengalir ke laut. Hasil pengukuran setiap lintasan berupa penampang bawah permukaan berdasarkan tahanan jenis dan ditentukan tinggi air tanah yang dihitung dari permukaan laut. Arah aliran air tanah dengan menghubungkan tinggi air tanah dari setiap lintasan pengukuran geolistrik tomografi. Hasil pengukuran Geolistrik pada 11 lintasan, di dapatkan kesimpulan adanya alur-alur sungai bawah tanah yang menghubungkan antara Goa Rowo dengan Goa Umbultuk. (Aditya. $Y$. , A.S.Soewaeli. , 2014)

Penggunaan garam terbanyak sebagai bahan perunut yang pernah dilakukan adalah perunutan sistem sungai bawah tanah di Tuttlingen-Jerman untuk mencari hubungan antara sebuah ponor dan mata air karst terbesar di Jerman Aaschquelle, yaitu $50.000 \mathrm{~kg}$ garam. Setelah durasi waktu 4 (empat) hari, konsentrasi terbesar garam di mata air tersebut teramati dengan konsentrasi $\mathrm{Cl}$ (Khlorida) mencapai $39 \mathrm{mg} / \mathrm{l}$.

Mc Donalds and Partners (1983) telah melakukan perunutan sistem sungai bawah tanah di karst Gunung Sewu, Yogyakarta. Hasil perunutan tersebut sampai sekarang masih digunakan oleh pihak-pihak yang berkepentingan terhadap pengembangan sumberdaya air karst di wilayah tersebut. (Haryono, 2014)

Goldscheider., et. al pada tahun 2008 menerapkan teknik perunut untuk menyelidiki alur sungai bawah tanah di daerah Karst Mammoth Cave, Amerika Serikat. Teknik perunut dapat membantu untuk memecahkan bagian alur sungai bawah tanah yang tidak dapat diakses oleh manusia, mengidentifikasi jaringan conduit yang aktif, serta geometri dan volume conduit. Selain itu, metode ini juga dapat digunakan untuk menyelidiki hubungan antara satu sistem alur sungai bawah tanah yang satu dengan yang lain.

\section{METODOLOGI}

Teknik perunutan diasumsikan dengan pendekatan blackbox, dimana input dan output suatu sistem telah diketahui akan tetapi bentuk dari sistem tersebut tidak diketahui seperti pada Gambar 2. Konsep ini diterapkan dalam penelitian sistem alur sungai bawah tanah di Kabupaten Blitar Selatan dengan input Goa Rowo dan output Goa Umbul Tuk. Pengujian dengan teknik perunutan ini dapat diketahui waktu yang dibutuhkan untuk menempuh jarak suatu sistem dari titik masuk (input) sampai titik keluarannya (output).
Kegiatan pengujian dengan teknik perunut di Goa Rowo dan Goa Umbul Tuk dilaksanakan dengan menggunakan larutan garam $\mathrm{NaCl}$, sebagai zat perunut yang dimasukkan ke dalam aliran air. Beberapa persyaratan yang harus dipenuhi dalam melakukan pengujian dengan teknik perunut menggunakan garam $\mathrm{NaCl}$, antara lain:

1 Tidak beracun, aman bagi kesehatan manusia dan binatang

2 Tidak bereaksi bila bercampur dengan air

3 Tidak terserap oleh media berpori / batuan

4 Tidak menimbulkan sikap penolakan dari masyarakat

5 Tidak menyebabkan penggumpalan tanah atau lumpur

6 Murah dan mudah dianalisis

Sejumlah $\pm 150 \mathrm{~kg}$ larutan garam $\mathrm{NaCl}$, ditumpahkan pada aliran di mulut Goa Rowo sebagai inlet, kemudian diukur perubahan nilai daya hantar listrik (EC) dalam air. Pengukuran dihentikan setelah nilai daya hantar listrik air kembali ke awal sebelum ditambahkan garam. Pada mulut Goa Umbul Tuk (outlet) pengukuran sama dilakukan seperti yang dilakukan pada mulut Goa Rowo. Metode ini efektif digunakan untuk perunutan aliran air tanah, tetapi perlu diketahui bahwa pergerakan air dalam tanah pun bisa saja menambah kandungan garam yang ada. Oleh karena itu sebelum perunutan dilakukan perlu dipelajari terlebih dahulu litologi batuan setempat.

Garam $\mathrm{NaCl}$ digunakan untuk uji perunutan ini, karena garam akan terurai dalam air menjadi kation dan anion dan akan meningkatkan nilai konduktivitas listrik (EC) dalam air dan mudah diukur menggunakan alat EC meter. Pengukuran menggunakan EC meter adalah cara yang paling sederhana untuk memonitor kandungan garam dalam air. Garam $\mathrm{NaCl}$ umumnya digunakan untuk teknik perunutan karena mudah dan murah, namun hanya efektif pada jarak yang tidak begitu jauh.

\section{HASIL DAN PEMBAHASAN}

\section{Kondisi fisik daerah karst Blitar Selatan}

Secara umum kondisi fisik wilayah bagian selatan dari Jawa Timur merupakan daerah perbukitan yang tersusun oleh batuan relatif tua, sebagian wilayah tersusun oleh batu gamping. Sumber air terdapat pada lokasi yang terpisah jauh secara lateral dan vertikal dari permukiman yang sangat tersebar. Ditinjau dari kondisi wilayah daratan, Jawa Timur bagian selatan hampir tidak terdapat sungai yang mengalir dengan debit cukup berarti. 


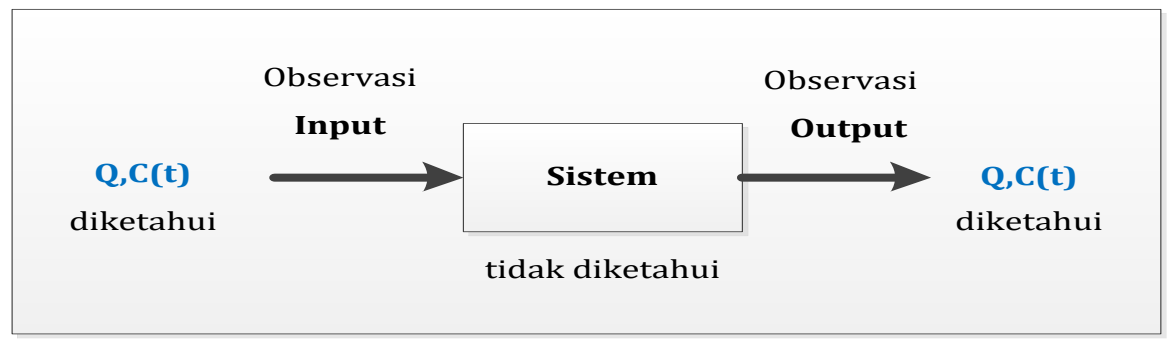

Gambar 2 Konsep pendekatan teknik perunutan (Modifikasi Uhlenbrook, 2010)

Sungai-sungai yang mengalir ke pantai selatan di wilayah ini umumnya memiliki debit kecil. Sistem tata air di daerah karst sangat khas dan unik, menyebabkan diperlukan teknologi pengelolaan dan pemanfaatan air khusus di daerah Karst Blitar Selatan, agar konservasi air dapat terjaga dan pemanfaatannya dapat berkelanjutan.

Morfologi wilayah Blitar Selatan berupa perbukitan bergelombang dengan dataran sempit yang semakin landai ke arah selatan menuju dataran pantai. Bentuk perbukitan yang ada mencerminkan jenis litologi batuan penyusun dan struktur geologinya. Topografi menunjukkan elevasi daerah ini berkisar antara 0 - $375 \mathrm{~m} \mathrm{dpl}$. Daerah paling tinggi terletak di Desa Wonotirto dengan elevasi $375 \mathrm{~m}$ dpl dan yang paling rendah terletak di lembah sekitar sungai dan pesisir pantai. Di daerah Blitar Selatan terdapat kemiringan lereng datar $(0-2 \%)$, terletak di sebagian Desa Tambakrejo yang merupakan daerah pantai dan dataran aluvial hasil rombakan dari litologi batuan yang ada di bagian utara. Kemiringan lereng curam (21 - 55\%) yang terletak di Desa Wonotirto, sebagian Desa Gunung Gede, Sumberboto, serta sebagian Desa Kaligrenjeng dan Desa Tambakrejo. Daerah dengan kemiringan lereng curam di dominasi oleh litologi batu gamping Formasi Wonosari dan breksi, lava dari Formasi Mandalika yang ada di bagian utara.

Selain Goa Rowo dan Umbul Tuk di Blitar Selatan teridentifikasi gua gua lainnya, seperti Goa Jambangan, Goa Rejo, Goa Jedog, dan Goa Nonong. Goa Jedog secara administratif terletak di Desa Plosorejo, Kecamatan Kademangan, Kabupaten Blitar. Goa Luweng secara administratif terletak di Dusun Prodo, Desa Ngrejo, Kecamatan Bakung, Kabupaten Blitar.

\section{Kebutuhan dan penggunaan air}

Kabupaten Blitar merupakan salah satu dari wilayah Propinsi Jawa Timur yang terletak di kawasan Selatan, berbatasan langsung dengan Samudera Indonesia. Secara geografis, Kabupaten Blitar terletak diantara 111 40'-112 10'Bujur Timur dan 7 58'-89' Lintang Selatan. Kabupaten
Blitar tercatat sebagai salah satu kawasan yang strategis dan mempunyai perkembangan yang cukup dinamis. Terdapat Sungai Brantas yang membelah wilayah Kabupaten Blitar menjadi dua, yaitu kawasan Blitar Selatan yang mempunyai luas $689,85 \mathrm{~km}^{2}$ dan kawasan Blitar Utara yang mempunyai luas wilayah 898,94 km². Kawasan karst di Blitar Selatan disebut kawasan Karst Pasiraman merupakan bagian dari wilayah Kecamatan Wonotirto dan Kecamatan Bakung. Sebaran penduduk di daerah karst umumnya sangat tidak merata. Biasanya penduduk tinggal di sekitar sumber air atau di jalur jalan yang mudah dilalui kiriman air. Jumlah penduduk pada kawasan Karst Pasiraman per kecamatan adalah untuk Kecamatan Wonotirto = 35.328 jiwa dan Kecamatan Bakung = 25.328 Jiwa. $(B P S, 2013)$

Di Desa Tumpakkepuh yang terdapat sungai bawah tanah, mata air dan telaga, memiliki jumlah penduduk sebanyak $=3.314$ jiwa. Kebutuhan air khusus untuk penduduk Desa Tumpakkepuh adalah $3.314 \times 60$ l/hari $=198,84 \mathrm{~m}^{3} /$ hari (Puslitbang Sumber Daya Air. 2012). Apabila penduduk di desa Tumpakkepuh akan memanfaatkan air dari aliran Umbul Tuk, perlu disediakan tandon air yang bisa menampung debit maksimum 2,5 l/s. Air tersebut dapat dialirkan secara grafitasi ke area pemukiman penduduk, sedangkan sisa aliran masih dapat digunakan di bagian hilir yakni di pantai Laut Selatan.

\section{Sistem Goa Rowo-Goa Umbul Tuk}

Hasil survei lapangan di alur sungai bawah tanah Goa Rowo sampai dengan Umbul Tuk, dibahas berikut ini. Goa Rowo berada di Dusun Kalimeneng, Desa Sidomulyo, Kecamatan Bakung, Kabupaten Blitar (Gambar 3). Arah alirannya pada posisi $\mathrm{N} 155^{\circ} \mathrm{E}$ menuju ke dalam goa yang diduga merupakan inlet dari aliran sungai bawah tanah yang keluar melalui Goa Umbul Tuk. Debit air yang masuk ke dalam goa adalah 100 l/s (hasil pengukuran Maret 2012). Di bagian mulut goa terdapat bangunan untuk membendung air, kemudian air diangkat keatas merupakan daerah pemukiman dengan dipompa dan didistribusikan 
ke pemukiman penduduk. Bangunan ini digunakan sejak Januari 2000. Selain dialirkan, beberapa penduduk memanfaatkan langsung ke sumber Goa Rowo untuk kegiatan sehari-hari, misalnya mencuci pakaian. Sisa air, mengalir masuk goa mengalir menuju Goa Umbul Tuk.

Umbul Tuk berada di Desa Tumpakkepuh Kecamatan Bakung Kabupaten Blitar (Gambar 4). Arah alirannya posisi $\mathrm{N} 200^{\circ} \mathrm{E}$ keluar goa menuju ke arah Laut Selatan. Perbedaan elevasi topografi antara Gua Rowo (+85 m dpl) dan Umbul Tuk (+65 m dpl ) adalah $20 \mathrm{~m}$, dengan jarak diperkirakan dari pembacaan peta adalah 1500 m. Air yang keluar dari Goa Umbul Tuk selanjutnya mengalir ke sungai kecil dengan debit sebesar 170 l/s (hasil pengukuran bulan Maret 2012). Aliran ke Sungai terusan dari Goa Umbul Tuk Arah posisi $\mathrm{N} 135^{\circ} \mathrm{E}$, mengalir ke arah Selatan dan bersatu dengan aliran yang keluar dari mata air Umbul Gedhang. Aliran terusan ini dan selanjutnya mengalir menuju laut (Pantai Pangi) dan hasil pengukuran debit aliran ini adalah $360 \mathrm{l} / \mathrm{s}$.

\section{Pengukuran Debit}

Pengukuran debit di mulut Goa Rowo dan Goa Umbul Tuk dilakukan 3 (tiga) kali pada bulan Maret, Mei, dan Oktober 2012, masing-masing menghasilkan nilai 100 dan 101 l/s. Pada bulan
Oktober yakni pada kondisi akhir musim kemarau debit Goa Rowo menurun drastis. Hasil pengukuran di lapangan sebesar 5,7 l/s, secara lengkap ditampilkan pada Tabel 3. Aliran air yang keluar dari mulut goa di Umbul Tuk sampai saat ini belum dialirkan untuk dimanfaatkan seperti di Goa Rowo, tetapi penduduk sekitar memanfaatkan untuk tempat pencucian dan sebagai kolam rekreasi untuk penelusuran goa.

Hasil pengukuran debit di Umbul Tuk pada musim hujan bulan Maret 170 l/s, menurun menjadi 122 l/s pada bulan April dan pengukuran terakhir pada musim kemarau menjadi 17 l/s. Di bagian Utara Goa Umbul Tuk terdapat Goa Semurup diduga menembus Goa Rowo. Air dari arah Goa Semurup mengalir masuk ke dalam mulut Goa Rowo melalui saluran terbuka dan banyak aliran masuk berupa rembesan dari kiri - kanan saluran. Arah aliran air kedalam goa N250 ${ }^{\circ}$. Jarak Goa Semurup ke Goa Umbul Tuk diperkirakan sepanjang $3 \mathrm{~km}$. Pada musim kemarau air tetap mengalir namun debitnya menurun. Debit terukur aliran sungai dari Mbul Gedhang yang menuju laut mencapai 360 l/s, berlokasi kurang dari 1 km dari Pantai Pangi. Sumber air ini sangat berpotensi untuk dimanfaatkan oleh penduduk sekitar atau dialirkan ke pantai Pangi untuk dipakai keperluan daerah pariwisata, yang sampai saat ini masih belum dikembangkan.

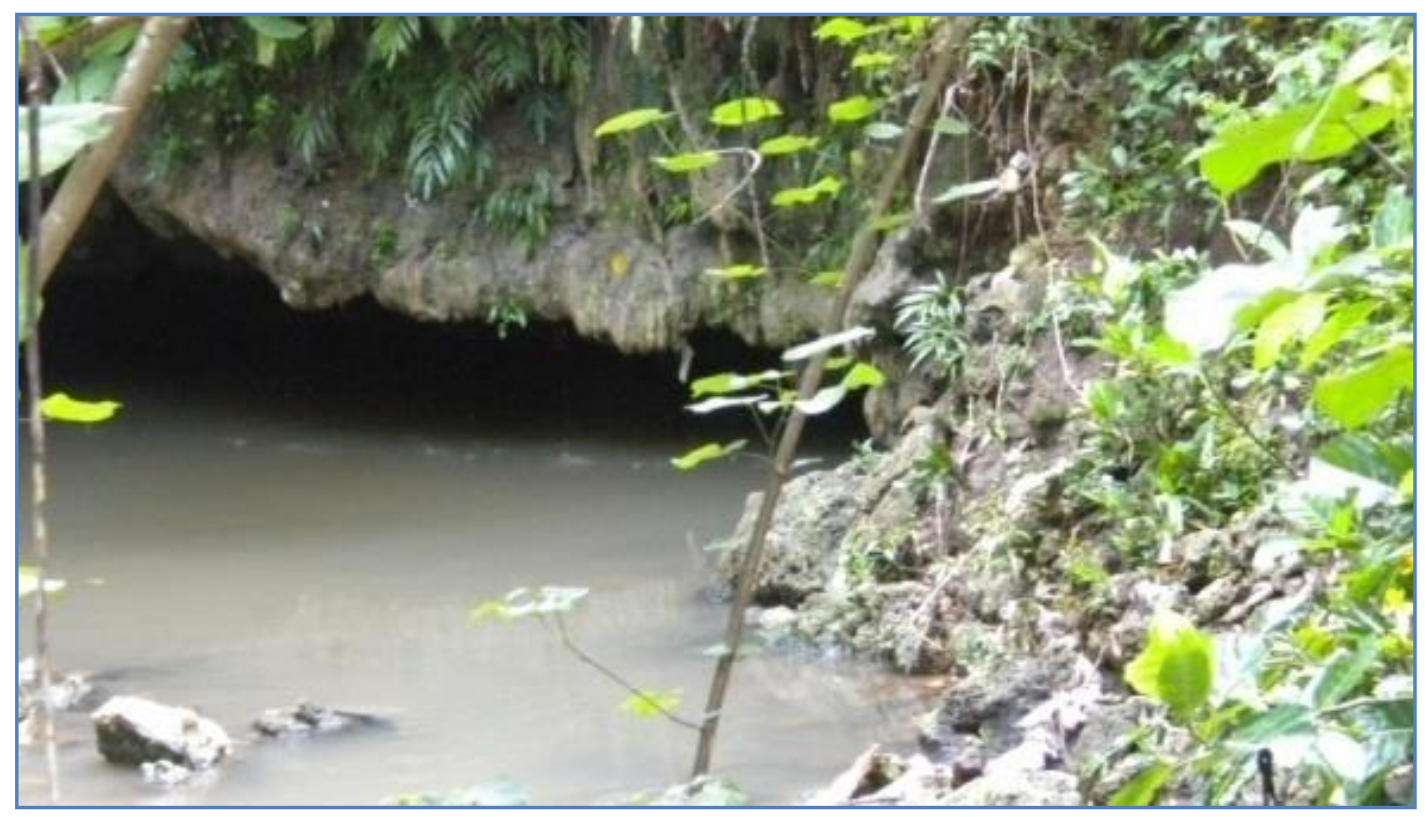

Gambar 3 Mulut Goa Rowo 


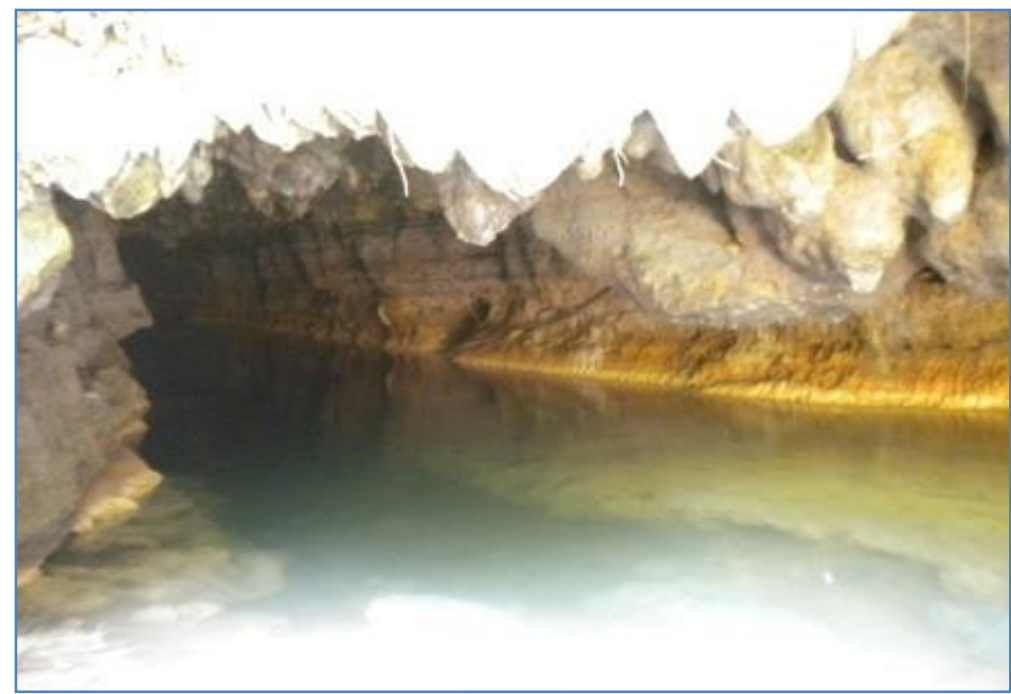

Gambar 4 Outlet Goa Umbul Tuk

Tabel 3 Hasil pengukuran debit di Goa Rowo dan GoaUmbul Tuk

\begin{tabular}{l|l|r|r|l}
\hline No & \multicolumn{1}{|c|}{$\begin{array}{c}\text { Waktu } \\
\text { pengukuran }\end{array}$} & $\begin{array}{c}\text { Mulut Goa Rowo } \\
(\mathrm{I} / \mathrm{s})\end{array}$ & $\begin{array}{c}\text { Keluaran Goa Umbul } \\
\text { Tuk (I/s) }\end{array}$ & \multicolumn{1}{|c}{ Keterangan } \\
\hline 1 & Maret & 100 & 170 & musim hujan \\
\hline 2 & Mei & 101 & 122 & akhir musim hujan \\
\hline 3 & Oktober & 5,7 & 17 & akhir musim kemarau \\
\hline
\end{tabular}

Tabel 4 Hasil pengukuran debit mata air di sekitar Gua Rowo dan Goa Umbul Tuk.

\begin{tabular}{c|l|l|r|l|r}
\hline No & \multicolumn{1}{|c|}{$\begin{array}{c}\text { Nama } \\
\text { Sumber Air }\end{array}$} & \multicolumn{1}{|c|}{ Desa } & \multicolumn{1}{c}{$\begin{array}{c}\text { Debit } \\
(\mathbf{I} / \mathbf{s})\end{array}$} & \multicolumn{1}{|c}{ Pemanfaatan } & $\begin{array}{r}\text { Elevasi } \\
\text { (mdpl) }\end{array}$ \\
\hline 1 & Kucur & Kampung Kepuh & 38,0 & Air bersih penduduk & 157 \\
\hline 2 & Timo I & Tambakrejo & 1,5 & Belum dimanfaatkan & 60 \\
\hline 3 & Timo II & Tambakrejo & 11,0 & Belum dimanfaatkan & 62 \\
\hline 4 & Putih & Pantai Pangi & 61,0 & Air bersih penduduk & 10 \\
\hline 5 & Tretes & Pantai Pangi & $<1$ & Air bersih penduduk & 12,5 \\
\hline 6 & Gedang & Tumpakkepuh & 16,0 & Air bersih penduduk & 25 \\
\hline 7 & Bedar & Tumpakkepuh & 9,6 & Air bersih penduduk & 45 \\
\hline 8 & Rowo Jambal & Kalimeneng & 9,0 & Air bersih penduduk & 91 \\
\hline 10 & Wgembuk & Wotgaleh & 2,8 & Air bersih penduduk & 95 \\
\hline 11 & Rawan & Lorejo & $<1$ & Air bersih penduduk & 214 \\
\hline 12 & Klewih & Lorejo & $<1$ & Air bersih penduduk & 260 \\
\hline
\end{tabular}

Sumber: Hasil pengukuran Oktober 2012 
Pengukuran debit dilakukan juga pada sumber air lainnya disekitar Goa Rowo dan Umbul Tuk yaitu di wilayah Kecamatan BakungWonotirto. Teridentifikasi \pm 23 mata air, tetapi yang dapat diukur hanya 12 buah mata air , seperti ditampilkan pada Tabel 4. Hasil pengukuran sesaat, besaran debit mata air yang terukur bervariasi mulai dari debit terkecil $<1$ l/s dan mata air terbesar 61 l/s yakni mata air Putih di Pantai Pangi. Hampir semua sumber air tersebut telah dimanfaatkan oleh penduduk untuk keperluan air bersih. Sumber-sumber air yang belum dimanfaatkan terutama terkendala dengan kesampaian lokasi yang sangat terjal. Sumber-sumber air tersebut diukur pada Bulan Oktober tahun 2012 yaitu akhir musim kemarau. Oleh karena itu beberapa sumber air menjadi kering dan air yang keluar melalui celah batuan sangat kecil sehingga debitnya belum bisa diukur

\section{Pemilihan dan Penentuan Jumlah garam NaCl untuk Uji Perunutan}

Pemilihan zat perunut bergantung pada analisis dampaknya terhadap lingkungan (Benrens et al, 2001 dalam Goldscheider, et.al, 2007), harga, dan kemampuan mendeteksi. Sumber air di Goa Rowo dan Goa Umbul Tuk setiap hari dimanfaatkan oleh penduduk sekitar, terutama pada pagi hari. Oleh karena itu penggunaan $\mathrm{NaCl}$ sebagai bahan perunut pada percobaan ini dinilai aman.

Jumlah garam $\mathrm{NaCl}$ yang digunakan untuk percobaan perunutan, dihitung menggunakan rumus Kass persamaan 1. Hasil perhitungan secara teoritis jumlah garam yang dibutuhkan minimal sejumlah $130 \mathrm{Kg}$, dengan koefisien perunut garam $(\mathrm{k})=1000$ dan faktor kondisi hidrogeologi $(\mathrm{B})=0,1$. Bogli (1980) mencontohkan bahwa untuk jarak tracing sekitar $3 \mathrm{~km}$ sampai dengan $5 \mathrm{~km}$ dibutuhkan setidaknya $500 \mathrm{~kg}$ garam untuk mencapai hasil yang optimal (Eko Haryono, Tjahyo Nugroho Adji, 2014).

Apabila penentuan garam ini dihitung berdasarkan perhitungan volume air sepanjang aliran $1300 \mathrm{~m}$, dengan asumsi aliran homogen maka jumlah garam yang dibutuhkan adalah 130 $\mathrm{kg}$, agar kandungan garam dalam air dapat terdeteksi oleh alat EC meter yakni $1 \mathrm{mg} / \mathrm{L}$

Rata-rata waktu tinggal dalam air dapat digambarkan dalam sebuah grafik konsentrasi tracer yang diukur ketika meninggalkan sistem dalam skala waktu. Jumlah zat perunut diukur oleh EC-meter yang dapat dikalikan dengan debit (atau volume air yang mengalir melewati sistem dalam satuan waktu) untuk menentukan berapa banyak zat perunut yang meninggalkan sistem dalam periode waktu yang diberikan (Bruckner, 2012).
Grafik tersebut dapat dibuat dari data DHL dari waktu ke waktu untuk menentukan jumlah zat perunut yang telah meninggalkan sistem. Kurva dihasilkan dari jumlah zat tersebut yang diukur terhadap waktu sejak zat perunut dimasukkan ke dalam sistem. Jumlah zat yang hilang dihitung dengan mengukur luas area di bawah

\section{Pengujian Perunutan Aliran Air Gua Rowo - Umbul Tuk}

Selain menggunakan metode tomografi dengan pengukuran geolistrik, metoda yang dapat digunakan untuk memetakan alur sungai bawah tanah adalah dengan teknik tracer (perunutan). Pada penelitian ini teknik perunutan yang dilakukan untuk mengetahui hubungan aliran air tanah antara Goa Rowo sampai dengan keluaran Goa Umbul Tuk. dengan panjang aliran antara 2 (dua) goa tersebut diperkirakan $1300 \mathrm{~m}$. Perunutan dilakukan membubuhkan larutan garam $\mathrm{NaCl}$ dengan memperhatikan debit dan kecepatan air di Goa Rowo. Garam NaCl merupakan bahan perunut yang pertama kali dipakai dan paling sering digunakan pada teknik ini, karena sifatnya yang sangat mudah larut dalam air. Penggunaan garam untuk media teknik ini memerlukan jumlah garam yang sangat banyak, terutama untuk mendeteksi jaringan sungai bawah tanah yang berjarak panjang dan debit yang besar. Jika jumlah garam yang dimasukkan ke air kurang, maka pada titik output yang diamati tidak akan terdeteksi adanya korelasi, walaupun sesungguhnya merupakan satu sistem dengan titik inputnya. Hal ini membuktikan bahwa adanya daya larut yang tinggi dari garam serta kondisi lorong selama transport membuktikan besarnya keterbatasan metode ini dengan garam. Bahan perunut lain yang dapat diamati secara kasat mata tidak memerlukan alat pengukur yaitu menggunakan busa plastik (alkylbenzene-sulphonate) dan arang teraktivasi. Busa plastik murah harganya dan terbukti berhasil baik pada kondisi tertentu. Sedangkan penggunaan arang teraktivasi harganya sangat mahal. Sebagai percobaan pendahuluan, telah dilakukan percobaan meniru bahan perunut busa plastik yaitu dengan memanfaatan sumber daya lokal seperti sekam. Zat perunut-perunut yang disebutkan ini tidak terlalu sering digunakan dan kadang mempunyai kegagalan dalam hal aplikasinya (Haryono cs, 2004). Peniruan bahan perunut yang dipakai adalah sekam (kulit gabah) yang dihanyutkan sebanyak 3 (tiga) karung besar (100 kg) pada mulut goa Rowo. Hasil pengamatan menunjukkan sekam tersebut hanyut mengikuti arus, namun tidak sampai ke keluaran mulut Goa Umbul Tuk, sehingga percobaan dengan sekam belum diperoleh petunjuk hubungan aliran antara Goa Rowo dengan Goa Umbul Tuk. 
Percobaan kedua dilakukan saat pemantauan aliran air di Goa Rowo memiliki debit sebesar 5,7 l/s dengan kecepatan aliran $0,17 \mathrm{~m} / \mathrm{s}$, dan debit di Goa Umbul Tuk 17 l/s. Penuangan $100 \mathrm{~kg}$ garam NaCL dilakukan pada kondisi awal kualitas air di gua Rowo adalah $620 \mu$ mhos/cm. Nilai daya hantar listrik tertinggi terukur pada menit ke-7 setelah penambahan garam $\mathrm{NaCl}$ yaitu 26.000 $\mu \mathrm{mhos} / \mathrm{cm}$. Kondisi kualitas air pada lokasi pemantauan kembali ke asal terjadi pada menit ke53. Hasil pemantauan parameter kualitas air selama 5,5 jam di Umbul Tuk belum menunjukkan adanya perubahan nilai daya listrik yang signifikan. Percobaan tracer dengan penambahan garam $\mathrm{NaCl}$ yang telah dilakukan ini, belum berhasil terkendala dengan debit aliran dari gua Rowo pada kondisi debit minimum 5,7 l/s. Hal ini diperkirakan di dalam goa terdapat aliran tambahan dari rembesan atap goa, atau ada aliran lain yang masuk ke dalam sistem ini, sehingga debit outlet bertambah dari inlet, seperti ditampilkan pada Tabel 3. Didalam goa karst biasanya banyak sekali rembesan yang mengalir melalui rekahan-rekahan, yang sering kontak dengan udara dan akan membentuk salaknit atau stalagnit

Percobaan selanjutnya dilakukan dengan menuangkan larutan garam $\mathrm{NaCl}$ sebanyak $150 \mathrm{~kg}$ pada kondisi debit Goa Rowo sebesar 8,4 l/s dengan kecepatan aliran 0,3 m/s. Hasil perhitungan diperkirakan kandungan garam dalam aliran tersebut adalah 1,15 $\mathrm{mg} / \mathrm{L}$, sedangkan batas diteksi kandungan garam dalam air adalah 1 mg/L menggunakan alat EC meter. Posisi pengamatan nilai daya hantar listrik dilakukan pada jarak $\pm 10 \mathrm{~m}$ dari lokasi penuangan dan hasil pengamatan ditampilkan pada Tabel 5 .
Sebelum garam ditumpahkan, nilai EC di Goa Rowo sebesar $760 \mu \mathrm{mhos} / \mathrm{cm}$. Nilai EC naik pada menit-menit pertama setelah garam ditumpahkan. Pada menit ke-8 terukur nilai daya hantar listrik tertinggi yakni $26.200 \mu \mathrm{mhos} / \mathrm{Cm}$. Puncak respon terjadi perubahan pada menit ke-9 dan 10 nilai daya hantar listrik mulai menurun, dapat dilihat pada Gambar 5. Grafik perubahan nilai daya hantar listrik kemudian berangsur-angsur stabil kembali di nilai $712 \mu \mathrm{mhos} / \mathrm{cm}$ setelah menit ke-54 .

Pengukuran nilai daya hatar listrik kemudian berpindah ke Goa Umbul Tuk, dan hasil pengukuran dapat dilihat pada Tabel 6. Kondisi awal nilai daya hantar listrik di Goa Umbul Tuk 600 $\mu \mathrm{mhos} / \mathrm{cm}$ dan debit aliran saat pengukuran pertama adalah 28 l/s. Nilai daya hantar listrik pada aliran diukur setiap 5 menit, menunjukan stabil pada 10 menit sampai dengan 2 jam pertama pengukuran. Nilai DHL kemudian naik bertahap, tetapi tidak menunjukkan angka yang signifikan pada jam ke-2 menuju ke-3. Nilai daya hantar listrik bertahap naik angkanya secara signifikan yaitu pada jam ke-3 menuju ke-4, selanjutnya pada pengukuran menuju jam ke-5 perlahan menurun kembali (Gambar 6).

Aliran dari Goa Rowo yang mengandung garam $\mathrm{NaCl}$ mengalir sepanjang $1300 \mathrm{~m}$ menuju Goa Umbul Tuk dengan kecepatan $0,3 \mathrm{~m} / \mathrm{s}$. Hasil perhitungan aliran tersebut akan sampai pada mulut Goa Umbul Tuk setelah 1,2 jam dan diperkirakan akan terjadi peningkatan nilai daya hantar listrik.

Tabel 5 Hasil pengukuran nilai daya hantar listrik di mulut Goa Rowo

\begin{tabular}{c|c|r|r|r|r|r|r|r}
\hline No & $\begin{array}{c}\text { Waktu } \\
\text { (menit) }\end{array}$ & $\begin{array}{c}\text { EC } \\
(\mu \mathrm{mhos} / \mathrm{Cm})\end{array}$ & No & $\begin{array}{c}\text { Waktu } \\
(\text { menit })\end{array}$ & $\begin{array}{c}\text { EC } \\
(\mu \mathrm{mhos} / \mathrm{Cm})\end{array}$ & No & $\begin{array}{c}\text { Waktu } \\
(\text { menit })\end{array}$ & $\begin{array}{c}\text { EC } \\
(\mu \mathrm{mhos} / \mathrm{Cm})\end{array}$ \\
\hline 1 & 0 & 760 & 12 & 12 & 17.400 & 23 & 34 & 2.800 \\
\hline 2 & 1 & 1.400 & 13 & 14 & 11.400 & 24 & 36 & 2.200 \\
\hline 3 & 2 & 1.800 & 14 & 16 & 8.900 & 25 & 38 & 2.000 \\
\hline 4 & 3 & 10.000 & 15 & 18 & 7.900 & 26 & 40 & 1.800 \\
\hline 5 & 4 & 15.100 & 16 & 20 & 6.700 & 27 & 42 & 1.700 \\
\hline 6 & 5 & 15.200 & 17 & 22 & 6.000 & 28 & 44 & 1.600 \\
\hline 7 & 6 & 19.400 & 18 & 24 & 7.100 & 29 & 46 & 1.500 \\
\hline 8 & 7 & 19.400 & 19 & 26 & 5.800 & 30 & 48 & 1.500 \\
\hline 9 & 8 & 26.200 & 20 & 28 & 5.000 & 31 & 50 & 1.400 \\
\hline 10 & 9 & 23.000 & 21 & 30 & 4.400 & 32 & 52 & 754 \\
\hline 11 & 10 & 23.100 & 22 & 32 & 3.400 & 33 & 54 & 712 \\
\hline
\end{tabular}



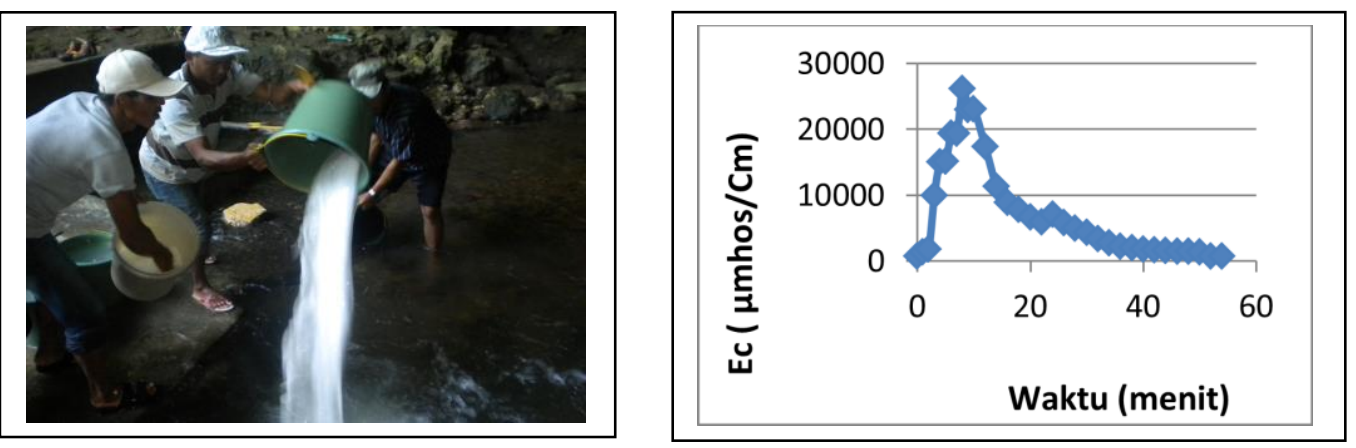

Gambar 5 Penumpahan garam NaCl dan Grafik Pemantauan DHL di Inlet Goa Rowo

Tabel 6 Hasil pengukuran nilai daya hantar listrik di mulut Goa Umbul Tuk

\begin{tabular}{l|c|r|c|r|r|r|r|r}
\hline No & $\begin{array}{c}\text { Waktu } \\
(\text { menit })\end{array}$ & $\begin{array}{c}\text { EC } \\
(\mu \mathrm{mhos} / \mathrm{Cm})\end{array}$ & No & $\begin{array}{c}\text { Waktu } \\
(\text { menit })\end{array}$ & $\begin{array}{c}\mathrm{EC} \\
(\mu \mathrm{mhos} / \mathrm{Cm})\end{array}$ & No & $\begin{array}{c}\text { Waktu } \\
(\text { menit })\end{array}$ & $\begin{array}{c}\text { EC } \\
(\mu \mathrm{mhos} / \mathrm{Cm})\end{array}$ \\
\hline 1 & 0 & 600 & 8 & 35 & 600 & 15 & 180 & 605 \\
\hline 2 & 5 & 600 & 9 & 45 & 600 & 16 & 240 & 611 \\
\hline 3 & 10 & 600 & 10 & 60 & 600 & 17 & 255 & 610 \\
\hline 4 & 15 & 600 & 11 & 75 & 600 & 18 & 270 & 610 \\
\hline 5 & 20 & 600 & 12 & 90 & 600 & 19 & 285 & 605 \\
\hline 6 & 25 & 600 & 13 & 105 & 600 & 20 & 300 & 605 \\
\hline 7 & 30 & 600 & 14 & 120 & 600 & 21 & 330 & 600 \\
\hline
\end{tabular}

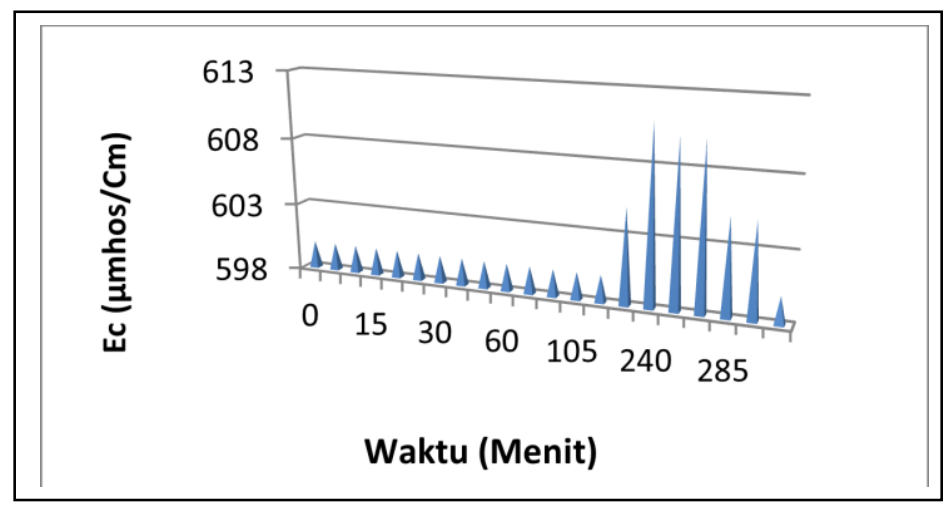

Gambar 6 Grafik Pemantauan DHL di mulut Goa Umbul Tuk

Hasil pemantauan di mulut goa Umbul Tuk menunjukkan perubahan terjadi setelah 2 jam dan puncak respon terjadi setelah 4 jam. Kondisi ini sudah diperkirakan akan terjadi, disamping karena di dalam goa karst biasanya banyak sekali rembesan yang mengalir melalui rekahan-rekahan juga aliran di dalam tidak homogen.

Berdasarkan hasil diskusi dengan penduduk setempat di dalam Goa Umbul Tuk telah ditemukan beberapa luweng yang cukup dalam. Oleh karena itu kecepatan aliran di dalam goa akan menurun, sehingga perjalanan aliran sampai ke mulut Umbul Tuk akan lebih lama dan air yang keluar dari mulut goa akan lebih banyak.

\section{KESIMPULAN}

Teknik perunut menggunakan $\mathrm{NaCl}$ berhasil mengungkap hubungan aliran antara Goa Rowo dan Goa Umbul Tuk sepanjang 1300 m. Aliran dari Goa Rowo membutuhkan waktu selama 4 jam untuk sampai di mulut Goa Umbul Tuk dengan debit bertambah besar karena di dalam goa karst banyak sekali rembesan yang mengalir melalui rekahan-rekahan. Aliran yang keluar dari mulut 
Goa Umbul Tuk ini selanjutnya bersatu dengan aliran dari Mbul gedang menuju laut Selatan dan debit terukur sebesar $360 \mathrm{l} / \mathrm{s}$.

Aliran sebesar $360 \mathrm{l} / \mathrm{s}$ berpotensi untuk dikembangkan pemanfaatannya, seperti dengan membuka area parawisata pantai Pangi di Laut Selatan. Pantai Pangi merupakan sebuah pantai teluk. tidak begitu luas, namun karena masih tergolong alami pantai ini belum lama dikenal publik, sehingga masih tergolong pantai wisata baru. Pantai ini berada dalam satu kawasan wisata dengan Goa Umbul Tuk. Secara administratif terletak di Desa Tumpakkepuh, Kecamatan Bakung, Kabupaten Blitar.

Pengujian dengan Tracer technique menggunakan garam $\mathrm{NaCl}$ ini sangat cocok diterapkan di wilayah Blitar Selatan, karena sistem sungai bawah tanah (goa/luweng) banyak teridentifikasi di wilayah ini berjarak pendek dan berada dekat pemukiman penduduk. Menggunakan garam $\mathrm{NaCl}$ sangat murah, mudah memakainya dan tidak berbahaya untuk lingkungan.

Selain Goa Rowo dan Umbul Tuk di Blitar Selatan teridentifikasi pula goa goa lainnya, seperti Goa Jambangan, Goa Rejo, Goa Jedog, dan Goa Nonong. Sumber air dari goa-goa ini berpotensi untuk dikembangkan pemanfaatannya. Dalam rangka pengembangan pemanfaatan sumber air ini, maka perlu diungkap pula keterhubungan antar goa, arah dan asal aliran serta berapa lama waktu yang dibutuhkan untuk mencapai keluaran tersebut, sehingga akan dapat memperkirakan jumlah air yang dapat dimanfaatkan secara berkelanjutan.

Hampir semua sungai bawah tanah yang membentuk goa-goa pada lingkungan karst di Blitar Selatan berpotensi untuk dijadikan obyek wisata oleh pemerintah daerah selain yang berdampak positif terhadap pendapatan daerah setempat juga masyarakat sekitar goa. Peran serta masyarakat sekitar sangat diharapkan juga, untuk turut serta menjaga goa-goa pada lingkungan karst demi keberlangsungan goa-goa karst yang terjaga tetap alami.

Penelitian ini merupakan upaya untuk menentukan potensi sungai bawah tanah dalam rangka pengembangan pemanfaatan air tanah di

daerah karst. Percobaan ini telah berhasil mengungkap hubungan antara sistem sungai bawah tanah antara Goa Rowo dan Goa Umbul Tuk. Pemanfaatan sungai bawah tanah untuk tujuan pengembangan dan pengelolaan yang berkesinambungan maka perlu dilakukan penelitian lanjutan untuk mempelajari keterhubungan beberapa sistim sungai bawah tanah (goa/luweng) yang terdapat di daerah penelitian. Untuk tujuan ini, teknik perunut baik perunut konservatif maupun perunut radioaktif adalah salah satu teknik yang sudah terbukti dapat mempelajari keterhubungan antara sistim sungai bawah tanah yang dipelajari. Penelitian ini merupakan kegiatan yang sangat strategis dan penting untuk turut berperan membantu dalam menjamin ketersediaan air baik untuk kebutuhan domestik, pertanian maupun industri. Hasil penelitian ini telah berhasil memberikan informasi ilmiah bagi pengelola kepentingan untuk dapat menerapkan sistim kelola sumber daya air yang lebih berdaya guna dan berkesinambungan (sustainable).

\section{Rekomendasi pengembangan pemanfaatan sumber-sumber air}

Berdasarkan hasil survei identifikasi dan evaluasi sumber-sumber air di Blitar Selatan, maka beberapa rekomendasi yang disampaikan untuk pengembangan sumber-sumber air selanjutnya. Sumber-sumber air di daerah karst, tidak selamanya mampu memenuhi kebutuhan air penduduk karena debit sumber air yang fluktuatif pada musim kemarau dan musim hujan, untuk itu perlu adanya konservasi demi menjaga kelestarian dan kontinuitas ketersediaan air secara kuantitas dan kualitas.

Konservasi dilakukan dalam rangka perlindungan terhadap sumber-sumber air dan perlindungan terhadap lingkungan di sekitar sumber-sumber air tersebut. Perlindungan pencemaran air, misalnya mencegah buangan limbah rumah tangga dan pusat peternakan yang masuk ke sistem jaringan air menuju mata air dan sungai bawah tanah.

Konservasi sebagai upaya untuk menjaga keberlanjutan dalam rangka melindungi kelestarian sungai bawah tanah, mata air dan daerah tangkapan airnya dari kerusakan. Konservasi mata air dapat diartikan sebagai menjaga keberlanjutan yaitu dalam rangka melindungi kelestarian mata air agar tidak mati, menjaga lokasi mata air dari pencemaran setempat dan menjaga DTA (daerah tangkapan air) mata air dari kerusakan. Indikasi saran tindak konservasi mata air secara struktur dilakukan untuk melindungi kawasan mata air dan DTA yang bersangkutan dengan upaya-upaya antara lain:

1 Perencanaan pengelolaan mata air;

2 Pemeliharaan kelangsungan fungsi resapan air dan daerah tangkapan air;

3 Pengendalian pemanfaatan mata air;

4 Pengisisan air pada daerah imbuhan mata air;

5 Perlindungan mata air dalam hubungannya dengan kegiatan pembangunan dan pemanfaatan lahan pada mata air; 
6 Pengendalian DTA bagian hulu;

7 Pengaturan daerah sempadan mata air sekurang-kurangnya berjarak 200 meter di sekeliling tepi masuk dan keluar aliran sungai bawah tanah (berdasarkan PP Nomor 38 Tahun 2011 tentang Sungai);

8 Rehabilitasi hutan dan lahan, dan/atau;

9 Pelestarian hutan lindung dan kawasan pelestarian alam.

(Puslitbang Sumber Daya Air, 2013)

Untuk masa mendatang tentunya ada kemungkinan pemanfaatan sumber-sumber air lainnya akan bertambah. Oleh karena itu sangat diperlukan informasi lebih rinci terhadap sumbersumber air yang dapat digunakan untuk air bersih yang dapat dikelola oleh perusahaan daerah air minum, atau oleh swadaya masyarakat, dengan demikian kebutuhan air bersih akan terlayani dengan baik

Upaya yang harus dilakukan dalam rangka pemanfaatan sungai bawah tanah tersebut, sejak awal perencanaan, pelaksanaan sampai dengan pengawasan harus berdasarkan data dan informasi lengkap baik fisik maupun data sosial (Pusat Lingkungan Geologi, 2007). Sumber-sumber air biasanya akan terganggu apabila penggunaan atau penyalahgunaan pemanfaatan sumber air.

\section{DAFTAR PUSTAKA}

Adhitya, Y., A.S. Soewaeli, 2014. Pemetaan Aliran Gua Rowo dengan Pengukuran Tomografi di Daerah Blitar. Jurnal Sumber Daya Air. Vol.10. No 1 Mei 2014. 43-56. Kementrian Pekerjaan Umum. Badan Penelitian dan Pengembangan, Pusat Penelitian dan Pengembangan Sumber Daya Air

Bruckner, M.Z. 29 Mei 2012. Using Hydrological Tracers to Characterize a Watershed. Microbial Life:

http://serc.carleton.edu/microbelife/research methods/environ sampling/hydrotrace.html (11 Februari 2014)

BPS, 2013, Kabupaten Blitar Dalam Angka. Badan Pusat Statistik Tahun 2013. Jakarta.

Davis, S.N., Thompson, G.M., Bentley, H.W., Stiles,G. 1985. An Introduction to Groundwater Tracers. Oklahoma : University of Arizona

Goldscheider, N., Meiman, J. Pronk, M., and Smart, C. 2008. Tracer Test in Karst Hydrogeology and Speleology. International Journal of Speleology, 37(1), $27-40$. Bologna (Italy). ISSN 0392-6672.
Haryono,E., Yuwono J. S. E., and Has C. A. T., 2004, The Archaic River Morphology and groundwater Condition in the Plaosan Temple Complex, The Indonesia Journal of Geography, vol. 36/2, pp. 73-83, 2004

Haryono,E., dan Tjahyo Nugroho Adji, Geomorfologi dan Hidrologi Karst, 2014, Kelompok Studi Karst Fakultas Geografi UGM, httphttp://geoenviron.blogspot.com/2014/11/ geomorfologi-dan-hidrologi-karst.html. (24 November 2014).

Hiscock ,K., 2005. Hydrogeology Principles And Practice. Blackwell Publishing, USA-UKAustralia

Paul, L.Y., 2007, Groundwater in the Environment, Blackwell Publishing, USA-UK-Australia

Pusat Lingkungan Geologi, 2007. Kumpulan Panduan Teknis Pengelolaan Air Tanah. Departemen Energi dan Sumber Daya Mineral Badan Geologi Pusat Lingkungan Geologi, Bandung

Puslitbang Sumber Daya Air, 2012. Model Sistem Tata Air Untuk Konservasi Di Daerah Karst Blitar Selatan. Kementrian Pekerjaan Umum. Badan Penelitian dan Pengembangan, Pusat Penelitian dan Pengembangan Sumber Daya Air

Puslitbang Sumber Daya Air, 2013. Pedoman Survei, Investigasi dan Desain dalam Pengelolaan Sumber Daya Air di Bentang Alam Karst. Kementrian Pekerjaan Umum. Badan Penelitian dan Pengembangan, Pusat Penelitian dan Pengembangan Sumber Daya Air

Uhlenbrook, Stefan. 2010. The Use of Artificial Tracers, in Particular Salt Tracers in Hydrology. Lecture Note : UNESCO-IHE Institute for Water Education, Delft, Netherlands

\section{UCAPAN TERIMA KASIH}

Ucapan terima kasih kami sampaikan kepada Prof. R. Dr. Ir Bambang Soenarto, Dipl.H.E,M.Eng, yang telah memberi masukan dan saran pada proses penyusunan makalah ini. Terima kasih juga kepada Sdr Herawati Nugraheni, S.Si dan anggota tim kegiatan Penelitian Sistem Tata air di daerah Karst Blitar Selatan yang telah membantu selama melakukan percobaan di lapangan. 